\title{
STUDY OF ELECTRONIC GOVERNMENT IN SUPPORTING PUBLIC SERVICES IN KUPANG CITY
}

\author{
William Djani \\ Department of State Administration Science \\ Nusa Cendana University \\ Kupang, Indonesia \\ williamdjani@gmail.com
}

\author{
Jenny Therikh and Umbu Pariangu \\ Department of State Administration Science \\ Nusa Cendana University \\ Kupang, Indonesia \\ jeny_therik62@gmail.com, pariangu25@gmail.com
}

\begin{abstract}
The Information Communication Technology Revolution is a potential to modernize government organizations, strengthen operations and make more responsive services to the needs of its citizens. This study aims to provide an overview of the public and the apparatus in the application of ICT in the field of Public Service; and the Kupang City Government's policy proposal in preparing resources for ICT implementation; identify the constraint factors in the application of ICT with the formulation of models in the application of ICT in the field of Public Service.
\end{abstract}

This type of research is descriptive qualitative, which describes the occurrence where the implementation of egovernment in support of public service in Kupang City, while data analysis used is Interactive technique from Miles and Huberman.

The results showed that the implementation of electronic government system in Kupang City has not been successful. This is because: First, the lack of awareness and understanding of the community in participating towards the use of electronic government; Secondly, the lack of resource preparation is visible on placement and expertise and the position of Operator Console which is only handled by some of the required employees and thus creates a high dependency on them as an Operator; Third, support in the form of budget is not a top priority in the development of electronic government and Fourthly, in terms of infrastructure for employees in Kupang City, especially in the data and information processing sections, several Local Agency Organizations including the One Stop Service and One Stop Integrated Service Department still use third parties in managing ICT systems in public services, and central government intervention on the civil service and Civil Registration of Kupang City.

The constraints faced are the lack of socialization from the authorized party in introducing and educating the apparatus that is always urgently needed which in turn creates a dependency in managing ICT and for the community on electronic government $t$ so as to make people apathetic towards the implementation of egovernment.

Keywords-e-government, public service

\section{INTRODUCTION}

In 2003, the government issued Presidential Instruction No. 3 of 2003 on National Policy and Strategy of e-Government Development in Indonesia. Similarly, other countries that have realized the importance of electronic government to improve the quality of public services, the Kupang municipal government also helped to apply the system electronic government, some of which are government agencies that have implemented systems of this electronic government is the Department of Population and Civil Registration and the Investment Service and One Stop Integrated Service of Kupang City.

Governments around the world are currently facing pressure from various parties to improve the quality of public services and active participation in the provision of information to the community and required to be more effective. This causes e-Government or electronic-based Governance to play an increasingly important role for all decision makers. Egovernment has become very popular in line with the development of information and communication technology, which essentially is the process of utilizing information technology as a tool to help running the system of government more efficiently.

In recent years, e-government development has gained significant momentum of being more transparent and efficient. In addition, the demand for governments to change from traditional agents and departmental-centric models becomes "Citizen-Centric" model. In fact, the application of egovernment is still considered inadequate by the e-government subscribers in the optimization of e-government utilization. Information and Communication Technology is now an indicator in determining the economy of a country. The high demand and penetration of digital devices in various aspects of human life directly create a gigantic industry in the field of technology and involve almost all the nations of the world, with increasing the value of business from day by day.

E-Government or Electronic-based government is increasingly playing an important role for all decision makers where the process of utilizing information technology as a tool 
to help running the system of government. ICT support applied at the Kupang municipal government will encourage and support the performance of municipal governments according to the principles of efficient and effective in improving the administration and public services.

The results showed that the application of electronic government in the Regional Agency Organization in Kupang City has not run well. The reason is not all the officials and people of Kupang city who still do not understand or know electronic government that applied in Kupang city. People are also still fairly apathetic to technological developments so as to the application of electronic government in local agency organizations that deal with public services not yet received special attention from the local community. Then there is still lack of infrastructure in the form of supporting facilities provided by the local agency organizations. Furthermore, on the other hand, the current government continues to optimize the effort to be able to hold the community involved in the introduction and utilization of electronic government but not make innovations to attract the public attention.

\section{Dialogue ABOUt THEORY}

E-Governance is the application of Information and Communication Technology to provide government services, exchange of information communication transactions, integration of several stand-alone systems and government-tocitizen, government-to-business, government to-government as well as back office processes and interactions within the overall governance framework. Through e-Governance, government services will be made available to citizens comfortably, efficiently and transparently. The three main target groups that can be distinguished in the Governance concept are government, community and business/interest groups. In e-Governance, there is no distinct boundary (Garson, 2006:1-2). In e-Governance, there are generally four basic models, namely government to citizens, government to employees, government to government and government to business (Garson, 2006:1-2).

\section{A. E-Governance in Public Service}

Among the many expectations of the Information Communication Technology revolution is the potential to modernize government organizations, strengthen their operations and make them more responsive to the needs of their citizens. Many countries have introduced ICT-based egovernment programs and use them to change the dimensions of multiple government operations, to create more accessible, transparent, effective, and accountable governments (AlKhouri, 2011:1).

In recent years, e-government development has gained significant momentum despite the financial crisis that crippled the world economy. For most governments, the recent financial crisis has triggered a resurgence to become more transparent and efficient. In addition, there is also a demand for governments to change from traditional agents and departmental centric models to "Citizen-Centric" models. The transformation is expected to improve the quality of life of citizens in terms of greater convenience in the availability of government services and thereby result in increased customer satisfaction and confidence in government (Al-Khouri, 2011:1).

Government agencies are increasingly embracing ICT to improve efficiency and integrate employees, partners and citizens seamlessly. E-government not only activates government services on the Internet, but rather the reconceptualization of services offered by the government in line with the expectations of citizens as the core of the reconceptualization (Al-Khouri, 2011:1-2).

The basic purpose is renewal, as well as integrated ICT applications in government to improve efficiency, effective, transparant, accountability and economics in government work and government employees, to improve the quality and availability of information and services provided to users of government employees and ensure more active participation of citizens in the decision-making process and disseminate democracy in the community. This ICT strategy does not directly solve the shortcomings of government organizations and work, but it is adopted solely to support reform and development. Prerequisite for the development of efficient government e-Administration that includes analysis of the current situation is linked to all relevant resources.

\section{B. ICT-based Government Administration Services}

Around the world, the public administration proposes several on line services: (a) to improve its operations (b) to make easy administrative procedures; and (c) to minimize the cost and delivery time of public services (West, 2004.). Some of the services that have been recorded are the most demanding of electronic services that public administration should provide (Steyaert, 2004)) such as: public information, on line payments, e-procurement, registration, permit requests, etc.

In e-government development, it is necessary to consider that e-government can be expanded further and broader to egovernance. According to Heeks (2001: 2), e-governance is defined as the utilization of ICT to support good governance. Furthermore, it is explained that e-governance includes:

1) e-Administration is to improve governance by saving money, by managing performance, by building strategic connections within the government itself, and by creating empowerment.

2) e-Citizen \& e-Services are connecting citizens with the Government by talking with citizens and supporting accountability, by listening to the community and supporting democracy, and by improving public services.

3) e-Society is building interaction outside the government by working better with business, by developing communities, by building cooperation with government, and by building civil society.

Government Administration Operations from an information technology perspective can be divided into three areas: 1) internal, 2) intra-government, and 3) external (with community). Many of these operations are far from benefiting from the use of ICT. 


\section{Factors Affecting the Success and Failure of E- Government}

Referring to the requirements described by Heeks (2001b: 17-19), readiness towards e-government success IS related to: (1) data infrastructure, (2) legal/law infrastructure, (3) institutional infrastructure, (4) human resource infrastructure, (5) technological infrastructure, and (6) leadership and strategic thinking. While Gil-Garciá and Pardo (2005) mention the 6 factors of success and failure of e-Government development, namely challenge: (1) quality of information and data, (2) information technology, (3) organization and managerial, (4) laws and regulations, and (5) institutional and environmental. While ADB (2011) found 7 success factors of e-Government: (1) Collaboration Degrees, (2) Strategy Alignment, (3) High Commitment Level, (4) Alignment, (5) Business Transformation, (6) Knowledge Management, and (7) Norm and Compliance.

\section{Public Service}

Basically public services can be measured using standards. Therefore, service standards can be established, both from the time required and the results. The implications of bureaucratic reform can have both positive and negative effects on public services. There are a lot of opinions about this among other things explained:

Hariyoso (2002: 162) there are several service dimensions that need attention from government bureaucracy, such as: (1) Service without discrimination from public-service institutions; (2) Implementation of the principle of simplicity, clarity, certainty, security, openness, efficiency, economics, equitable justice, and timeliness; (3) Qualified, in the sense of conformity with suit, suitability for use and freedom from disability; (4) Touchable, reliable, quality accountability of service, assurance, and empathy; (5) Quality-oriented that is characterized by active participation, empathy and satisfaction served.

In the view of Ramaswamy (2012), the essence of public service should refer to the proposition that the products of government can be marketed to the public (need marketed to public) should be oriented to service culture through the creation of customer service satisfaction. Ramaswamy's view shows the political value of the public bureaucracy service to the political position of the government. The government gets taxes from the public. Therefore the government must provide good services and quality to the public. The government needs to identify what the public wants as well as what service model should be developed.

In the reciprocal relationship between the government as the service provider and the public as the user, there are several matters to be considered by the bureaucracy as the service provider as expressed by Nisjar (1997: 195), namely: (1) Service procedures should be easy to understand and easy to implement, so avoid excessive bureaucratic practices, time consuming; (2) Services are provided clearly and certainty, so that there is clarity to the user; (3) Providing effective and efficient service; (4) Service quickly and on time; and (5) In various service activities both technical and administrative, users are always treated with the motto of customer is king and customer always right.

The quality of service according to Fitzsimmons, (2012: 204) can be seen in five dimensions: (1) Reliability, ability to provide accurately and correctly, the type of service that has been promised to consumers/customers; (2) Responsiveness, awareness or desire to help the consumer and provide fast service; (3) Assurance, knowledge or insight, courtesy, politely, confidence of the service provider, and respect for consumers; and (4) Empathy, the willingness of service providers to approach, provide protection, and strive to know the wants and needs of consumers; (5) Tangibles, the appearance of employees and other physical facilities such as devices or equipment that support the service.

However, much more fundamental is defining the core characteristics of public service seen as: first, political dominance rather than economic objectives; secondly, the virtue of citizens and not consumers, and thirdly, it is necessary to serve several multi-dimensional customers.

The kin of this used qualitative appoach that purpose to describe the related of phenomenon e-government support the public service in Kupang city. The source data consist of informant, event, and document.

\section{RESEARCH METHODS}

The aggregation data of technique with use observation, interview, and documentatio. While the data analysis techniques performed by using qualitative analysis with follow the steps proposed by Miles, Huberman and Saldana, (2014) include: analysis of 3 concurrent that current activities: (1) the data of condensation, (2) display data, and (3) conclusion is an interactive process.

\section{DISCUSSION}

The application of electronic government in Kupang City regional organization is intended to know and describe the success of electronic government implementation in supporting public service and analyze the obstacles in electronic government (e-government). In the context of electronic government (e-government), it is intended that in the government service activities can provide ease for both government and society electronically. The services provided or obtained are no longer manually but by electronic use of computers and Internet in them. So as has been described previously with the focus studied in this research is in accordance with important aspects of the success of electronic government (e-government), namely: Understanding of government and society on ICT, Resource Policy including Human Resources (HR), Infrastructure, and Budget Support, and constratints faced in electronic government (e-government) application.

\section{A. Apparatus and public understanding for the e-government}

Electronic government or so-called e-government has been applied also in Kupang Municipal Government. The most important aspect of electronic government (e-government) development is the intention to create governance in which 
many sectors are involved and interact with each other aiming to improve the process of policy making and public service by increasing the opportunity for participation. Understanding the various actors is expected in the application of electronic government (e-government). Public understanding of ICT is intended to know the benefits in obtaining services and the extent to which the success of the application of the electronic government (e-government).

This research proves that the implementation of electronic government (e-government) in the Local Agency Organization that handles public services in Kupang City related to the understanding of the apparatus and the community is still lacking. This can be seen from several local agency organizations including the One Stop Service Office of Capital Investment and Integrated Service of Kupang City still using third party in creating Information Technology system in public service. From the side of society seems the understanding of society is still low and have apathy in the development of technology, especially the application of electronic government at the Local Agency Organization of Kupang City. However, the apathy of the community is due to the party who has the authority that is still lacking in conducting socialization and providing special education about electronic government to the public.

\section{B. Resource Policy}

The resource policy pursued by Kupang Municipal Government is to support the application of electronic government in improving the quality of public services. The development and improvement of human resources, especially government apparatuses, both as developers, managers and users of e-government are the factors that contribute to determine even the key to successful implementation and development of e-government. Therefore, it is necessary to improve the capacity of human resources and structuring in the utilization, with a mature and comprehensive planning in accordance with the needs, and its implementation should be done in stages and sustainable.

This research shows that the implementation of egovernment in the Local Agency Organization in the provision of public services in Kupang City related to human resources policy has been done by involving in trainings related to basic tasks and functions, but still seen lack of preparation of human resources managing the e-government. It can be seen from the placement of employees, especially in the data processing and information sections that are not adapted to the skills and levels of education and employees who served as consular operators are only handled by people who feel themselves are needed so always creates dependency considering the scope of work includes elements of bureaucracy and society.

The policy pursued by the Kupang Municipal Government is always to include in the training that supports the main tasks and functions, but because of the interest as a consular operator is minimum, but almost every Local Agency Organization should be handled at least one person, then they are needed in facilitating ICT activities that can create dependence on operator console.

\section{Government Support}

Support and commitment of the Central and local government of Kupang City in supporting the application of egovernment is a key factor. The availability and consistency of this budget is a great support for developing e-government that has been implemented. Therefore, government support occupies a very important role. If government support is not provided, then certainly e-government also will not run smoothly.

Limitations of funding in e-government implementation can have an impact on the low quality of public service delivery based on technology. The main challenge for the government is able to provide cheap and quality technology access services, so that in this condition the government must always be strategic in building e-government network even though limited funding. Although the use of information technology does not have to be analogous to high funding needs but in planning needs in the budget tend to be limited.

The results of this study show that the application of egovernment in Local Agency Organization of Kupang City in public service about government support in general is good, but for budget provision in the field of application and development of e-government has not become a top priority for Local Agency Organization of Kupang City.

\section{Constraints faced in the Application and Implementation of electronic government (e-Government) at the Local Agency Organization of Kupang City}

Based on the results of interviews and observations conducted by researchers who become constraints in the application and implementation of e-government is the lack of operators and public knowledge of public service website is still lacking, so to rely on public participation in accessing the website will be difficult. It is solely due to the lack of socialization by the party who has the authority in providing education to the apparatus and the community and the implementation of socialization that is still less intense. The socialization intended is a socialization that specifically introduces and provides specific education to discuss the use of e-government in Public Services, given that e-government applied has reached the stage of the transaction.

\section{CONCLUSION}

Based on the above explanation then some conclusions from the writing of the paper as follows:

1) In the application of e-government, the understanding of the apparatus and the people of Kupang City is still lacking. This lack of public participation on the use of e-government which causes the apathetic community to technological change is due to the lack of special socialization by those who have authority in introducing e-government on society.

2) In the policy and placement of its human resources, the Local Agency Organization (LAO) of Kupang City, especially in the Data Processing and Information Section who served as the overall implementer, is not adjusted to the education major they have, only in the 
field of computer they can understand and control. For Operator Console itself, there are inequalities considering its duties that concurrently not only serve the apparatus but also the community. It shows the lack of human resource preparation in e-government application.

3) In the field of infrastructure is very supportive of Data Processing and Information Section in carrying out its duties and functions. It can be seen from the facilities and infrastructure available in it is very sufficient and adequate. However, the infrastructure that is intended by the community, especially the computers used by the public to access the website of public_service.go.id is still inadequate.

4) At this stage of government support, it is generally good enough to see the provision of budgeted funds for the Local Agency Organization (LAO) of Kupang City. However, the support of the central government specifically for the application and development of egovernment itself in the Office of Population and Civil Registration of Kupang City is still minimal and the pattern of promotion and staff mutation is still through the approval of the Central Government in this case the Ministry of Home Affair.

5) The constraints faced in applying e-governmet in the Local Agency Organization (LAO) of Kupang City is the lack of intensive socialization of e-government in particular to make the attitude of people who are still apathetic and not open to the openness of changes in information and communication technology.

Therefore, the recommendations submitted for placement of human resources, employees who handle ICT at the Local Agency Organization (LAO) of Kupang City should be adjusted to the level of education and expertise of each employee, so that in carrying out its duties and functions can run properly and quickly. Provision of infrastructure, especially for the community needs to be improved again. The government should be able to improve or increase the infrastructure, especially computers.

\section{REFERENCES}

[1] Andersen, K.V., 2006. 'E-government: five key challenges for management', The Electronic Journal of e-Government, Vol. 4, No. 1, pp.1-8.

[2] Al-Khouri, A. M. (2011) An Innovative Approach For E-Government Transformation. pdf accessed, February 01, 2016.

[3] Fitzsimmons Allan K. (2012). Reforming Federal Land Management: Cutting the Gordian Knot. Rowman \& Littlefield Publishers.

[4] Garson, D.G. (2006). Public Information Technology and EGovernance. Sudbury, MA: Jones and Bartlett Publishers.

[5] Hariyoso S. (2002). Bureaucratic Update and Public Policy. Civilization.

[6] Heeks, Richard. 2001b. Understanding e-Governance for Development. i-Government Working Paper Series, Paper No. 11, Institute for Development Policy and Management, University of Manchester, Manchester, UK.

[7] Kim Viborg Andersen, (2009), e-Government: Five Key Challenges for Management.

[8] Milles, Matthew B., A. Michael Huberman \& Saldana (2014). Qualitative data analysis: a methods sourcebook. Edition 3. SAGE Publications, Inc. Thousand Oaks, California 91320.

[9] Nisjar, S. Karhi. (1997). "A few notes on good governance, Journal of Administration and Development", Volumes $1 \& 2$.

[10] PIU UK. 2000. Electronic Government Services for the 21st Century. Performance and Innovation Unit, Cabinet Office, UK, London

[11] The Department of Human Services (2011). Service Delivery Reform: Transforming government service delivery. diunduh dari http://www.humanservices.gov.au/spw/corporate/aboutus/resources/service-delivery-reform-overview.pdf accessed, February $05,2016$.

[12] Wikidepia (2013) E-Governance.From Wikipedia, the free encyclopedia diunduh dari http://en.wikipedia.org/wiki/E-Governance. Accessed February 01, 2016. 